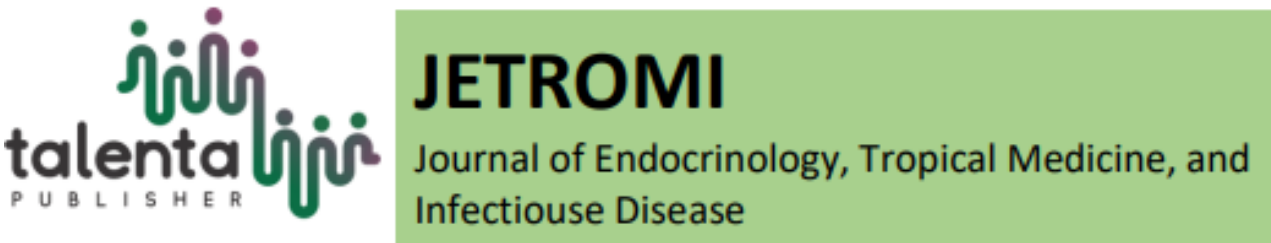

\title{
Relationship Between Triglycerides and Glucose Index (TyG) And Lipid Profile in Patients with Dyslipidemia Treated with Bay Leaf Extract [Syzygium Polyanthum (Wight) Walp]
}

\author{
Catur Prianwari ${ }^{1}$, Santi Syafril ${ }^{2}$ \\ ${ }^{1}$ Resident Department of Internal Medicine, Faculty of Medicine, University of North Sumatra \\ ${ }^{2}$ Endrocrinology and Diabetes Division, Department of Internal Medicine, Faculty of Medicine, \\ University of North Sumatra
}

\begin{abstract}
Background: Insulin Resistance (IR) causes a metabolic disorder including hyperglycemia, high blood pressure, and dyslipidemia. The purpose of the study was to assess the relationship of Triglycerides and Glucose Index (Tyg) decline relationship with lipid profile after bay leaf extract treatment in dyslipidemia patients. Method: Fifteen dyslipidemia patients were administered $2 \times 200 \mathrm{mg}$ salam leaf extract capsules for 30 days. Criteria dyslipidemia is defined as one of the following: total cholesterol level $\geq 240 \mathrm{mg} / \mathrm{dL}$, triglyceride levels $\geq 150 \mathrm{mg} / \mathrm{dL}$, LDL cholesterol levels $\geq 140 \mathrm{mg} / \mathrm{dL}$, HDL cholesterol levels $<40 \mathrm{mg} / \mathrm{dL}$, or the use of lipid-lowering drugs. Blood samples lipid profile for biochemical tests were drawn in the morning after fasting $12 \mathrm{~h}$. Anthropometric BMI and waist circumference measures were taken using standard procedures. The TG/HDL-C ratio was calculated by dividing the serum concentration of TG by HDL-C measured in $\mathrm{mg} / \mathrm{dL}$. TyG index was calculated based on formula: $\mathrm{Ln}$ [TG (mg/dL) x FG (mg/dL). Result: After 30 days of salam leaf extract treatment, there was a significant correlation of TyG reduction with parameters TC, LDL-C, TG, TG/HD ratio (p: 0.025*, p: 0.001*, p: 0.013*, sequentially) Conclusion: There is a significant correlation between Tyg reduction with TC, TG, and $\mathrm{TG} / \mathrm{HDL}$, which leads to a decrease in cardiovascular risk in dyslipidemia patients.
\end{abstract}

Keyword: TyG, Dyslipidemia, Syzygium Polyanthum (Wight) Walp

\begin{abstract}
Abstrak. Latar belakang: Resistensi insulin (RI) menyebabkan gangguan metabolisme termasuk hiperglikemia, tekanan darah tinggi, dan dislipidemia. Tujuan penelitian adalah menilai hubungan penurunan index $T y G$ dengan profil lipid setelah pengobatan ekstrak daun salam pada pasien dislipidemia. Metode: Lima belas pasien dislipidemia diberikan $2 \times 200$ mg kapsul ekstrak daun salam selama 30 hari.Dan Kriteria dislipidemia didefinisikan sebagai salah satu dari yang berikut: tingkat kolesterol total $\geq 240 \mathrm{mg} / \mathrm{dL}$, kadar trigliserida $\geq 150 \mathrm{mg} / \mathrm{dL}$, kadar kolesterol $L D L \geq 140 \mathrm{mg} / \mathrm{dL}$, kadar kolesterol $\mathrm{HDL}<40 \mathrm{mg} / \mathrm{dL}$, atau penggunaan obat penurun lipid. Sampel darah profil lipid untuk uji biokimia diambil pada pagi hari setelah puasa $12 \mathrm{jam}$. Pengukuran IMT antropometri dan lingkar pinggang menggunakan prosedur standar. Rasio TG / HDL-C dihitung dengan membagi konsentrasi serum $T G$ dengan $H D L-C$ diukur dalam $m g / d L$. Indeks $T y G$ dihitung berdasarkan rumus:
\end{abstract}

${ }^{*}$ Corresponding author at: Resident Department of Internal Medicine, Faculty of Medicine, University of North Sumatra

E-mail address: prianwaricatur@gmail.com 
Ln [TG $(\mathrm{mg} / \mathrm{dL})$ x FG $(\mathrm{mg} / \mathrm{dL})$. Hasil: Setelah pengobatan ekstrak daun salam selama 30 hari, terdapat korelasi signifikan penurunan $T y G$ dengan parameter $T C, L D L-C, T G$, rasio TG/HD (p: $0.025^{*}, p: 0.001^{*}, p: 0.013^{*}$, secara berurutan). Kesimpulan: Terdapat korelasi yang signifikan antara penurunan $T y G$ dengan $T C$, TG dan TG/HDL, yang menujukan penurunan risiko kardiovaskular pada pasien dislipidemia

Kata Kunci: TyG, Dislipdemia, Syzygium Polyanthum (Wight) Walp

Received 22 October 2020 | Revised 24 November 2020 | Accepted 30 November 2020

\section{Introduction}

Insulin resistance (IR) causes decreased cell sensitivity to insulin and is a central characteristic of metabolic syndrome (MS). IR tends to cause metabolic disorders including hyperglycemia, high blood pressure, and dyslipidemia all associated with diabetes, atherosclerosis, and cardiovascular disease. IR evaluation requires advanced methods and is not available in daily clinical practice. [2] Hyperinsulinemic-euglycemic clamp is a direct method of measuring IR and is considered a gold standard procedure, but difficult to perform in daily practice. Instead of IR examination includes the assessment of homeostatic IR (HOMA-IR) models i.e. measurement of fasting glucose and insulin levels. [3] Due to the difficulty of assessing the RI, sought other practical ways.[4] Other alternatives assess IR by measuring plasma TG and HDL cholesterol (TG/HDLC),[5] and TG/plasma/glucose called triglyceride and glucose index (TyG).[6] TyG is associated with HOMA-IR, insulin suppression tests, and hyperinsulinemic-euglycemic clamps. [7]

Bay leaves contain tannin, galokatekin, flavonoids, saponins (triterpenoid), and essential oils (sesquiterpenes). Bay leaves also contain several vitamins, including vitamin A, vitamin $\mathrm{C}$, vitamin E, thiamine, riboflavin, niacin, vitamin B6, vitamin B12, and folate. The results of in vitro studies showed that flavonoids work as inhibitors of the HMG-CoA reductase enzyme so that cholesterol synthesis decreases. An estimated 75 - 80\% of people in developing countries and $25 \%$ in developed countries use traditional medicine as first-line treatment. The administration of bay leaf extract $400 \mathrm{mg}$ per day for 30 days there was a significant decrease in TC, LDL, TG (p: 0.012, p: 0.035, p: 0.009, sequentially) in dyslipidemia patients.[8].

The purpose of the study was to assess the relationship of TyG index decline as a sign of RI with lipid profile after treatment of bay leaf extract in dyslipidemia patients

\section{Method}

Fifteen dyslipidemia patients were given $2 \times 200 \mathrm{mg}$ of bay leaf extract capsules for 30 days. Subject dyslipidemia with other inflammations, infections, use of anti-inflammatory drugs, and secondary dyslipidemia excluded from the study. Dyslipidemia criteria are defined as one of the following: total cholesterol levels $\geq 240 \mathrm{mg} / \mathrm{dL}$, triglyceride levels $\geq 150 \mathrm{mg} / \mathrm{dL}$, low-density lipoprotein (LDL) cholesterol levels $\geq 140 \mathrm{mg} / \mathrm{dL}$, high-density lipoprotein (HDL) cholesterol levels $<40 \mathrm{mg} / \mathrm{dL}$, or the use of lipid-lowering drugs. Blood samples lipid profile for biochemical 
tests were drawn in the morning, after fasting $12 \mathrm{~h}$. Anthropometric measures were taken using standard procedures. [9] Waist circumference $(\mathrm{cm})$ was measured halfway between the lower lateral margin of the last rib and the anterior superior region of the iliac crest while standing, using a flexible, not distensible measuring tape. Body mass index was calculated as weight $(\mathrm{kg}) / \mathrm{height}$ (m)2. The TyG index was calculated as the natural logarithm $(\mathrm{Ln})$ of the product of plasma glucose and TG using the formula: Ln (TG [mg/dL] A glucose [mg/dL]/2).[6] The TG/HDL-C ratio was calculated by dividing the serum concentration of TG by HDL-C measured in $\mathrm{mg} / \mathrm{dL}$. TyG index was calculated based on formula: $\mathrm{Ln}$ [TG $(\mathrm{mg} / \mathrm{dL}) \times \mathrm{FG}(\mathrm{mg} / \mathrm{dL}) / 2]$, according to the previous studies. [10]

All statistical analyses were performed using the SPSS statistical package for Windows (version 16.0, SPSS). Kolmogorov-Smirnov test was used to test the normality of the distribution of variables. The differences within groups were analyzed by the dependent t-test where appropriate. Univariate correlation coefficients were determined by Spearman analysis.

\section{Result}

In table 1, all study patients were male, dyslipidemia and overwight/obese.

Table 1 Basic data of research subjects

\begin{tabular}{lc}
\hline \multicolumn{1}{c}{ Variable } & $(\mathrm{n}=15)$ mean $\square \mathrm{SD}$ \\
\hline Age (years) & $50.40 \pm 5.22$ \\
WC $(\mathrm{cm})$ & $88,33 \pm 7,18$ \\
BMI $\left(\mathrm{kg} / \mathrm{m}^{2}\right)$ & $27.54 \pm 3.22$ \\
FBS $(\mathrm{mg} / \mathrm{dL})$ & $94,20 \pm 15,03$ \\
TC $(\mathrm{mg} / \mathrm{dL})$ & $229,13 \pm 14,99$ \\
LDL-C $(\mathrm{mg} / \mathrm{dL})$ & $155,00 \pm 22,55$ \\
HDL-C (mg/dL) & $51,13 \pm 7,73$ \\
TG $(\mathrm{mg} / \mathrm{dL}$ & $149,93 \pm 70,56$ \\
TG/HDL & $3.10 \pm 1.84$ \\
TyG & $4.80+0.41$
\end{tabular}

Note: WC: waist circumference; BMI: body mass index; FBS: fasting blood sugar; TC: total cholesterol; LDL-C: low density lipoprotein; HDL-C: high density lipoprotein; TG: triglyceride: TyG: Triglycerides And Glucose Index

In table 2, there were significant differences in TC, LDL-C, TG, TG/HDL ratios, while TyG decreased but not significantly. 
Table 2 Differences in TyG and lipid profile after treatment

\begin{tabular}{lccc}
\hline \multicolumn{1}{c}{ Variabel } & $\begin{array}{c}\mathbf{D}_{\mathbf{0}} \\
\text { Mean } \pm \mathrm{SD}\end{array}$ & $\begin{array}{c}\mathbf{D}_{\mathbf{3 0}} \\
\text { Mean } \pm \mathrm{SD}\end{array}$ & pa \\
\hline WC $(\mathrm{cm})$ & $91.46 \pm 4.43$ & $91.50 \pm 4.37$ & 0.109 \\
BMI $\left(\mathrm{kg} / \mathrm{m}^{2}\right)$ & $27.54 \pm 3.21$ & $27.53 \pm 3.19$ & 1.000 \\
FBS $(\mathrm{mg} / \mathrm{dL})$ & $94.20 \pm 15.03$ & $89.06 \pm 13.24$ & 0.116 \\
TC $(\mathrm{mg} / \mathrm{dL})$ & $229,13 \pm 14,99$ & $217,53 \pm 23,10$ & $0,012^{*}$ \\
LDL-C $(\mathrm{mg} / \mathrm{dL})$ & $155,00 \pm 22,55$ & $145,67 \pm 29,37$ & $0,035^{*}$ \\
HDL-C $(\mathrm{mg} / \mathrm{dL})$ & $51,13 \pm 7,73$ & $50,07 \pm 7,5$ & 0,318 \\
TG $(\mathrm{mg} / \mathrm{dL}$ & $149,93 \pm 70,56$ & $112,13 \pm 37,92$ & $0,009^{*}$ \\
TG/HDL & $3.1 \pm 1.84$ & $2.40 \pm 0.98$ & $0.040^{*}$ \\
TyG & $4.80 \pm 0.41$ & $4.66 \pm 0.48$ & 0.317 \\
\hline
\end{tabular}

Note: WC: waist circumference; BMI: body mass index; FBS: fasting blood sugar; TC: total cholesterol; LDL-C: low density lipoprotein; HDL-C: high density lipoprotein; TG:

triglyceride: TyG: Triglycerides and Glucose Index.

In table 3. There is a significant correlation between TyG and TC, TG and TG/HDL

Table 3 Correlation between TyG and lipid profiles after treatment

\begin{tabular}{lcc}
\hline \multicolumn{1}{c}{ Variabel } & $\mathbf{r}$ & $\mathbf{p}$ \\
\hline WC $(\mathrm{cm})$ & 0.297 & 0.283 \\
BMI $\left(\mathrm{kg} / \mathrm{m}^{2}\right)$ & 0.246 & 0.377 \\
FBS $(\mathrm{mg} / \mathrm{dL})$ & 0.164 & 0.559 \\
TC $(\mathrm{mg} / \mathrm{dL})$ & 0.573 & $0.025^{*}$ \\
LDL-C (mg/dL) & 0.475 & 0.074 \\
HDL-C (mg/dL) & -0.278 & 0.315 \\
TG $(\mathrm{mg} / \mathrm{dL})$ & 0.786 & $0.001^{*}$ \\
TG/HDL & 0.625 & $0.013^{*}$
\end{tabular}

Note: WC: waist circumference; BMI: body mass index;

TC: total cholesterol; LDL-C: low density lipoprotein; HDL-C: high density lipoprotein; TG:triglyceride:

\section{Discussion}

Average Indeks TyG and TG/HDL-C ratio are very high in subjects with MS compared to those without MS. TyG index also increases as the number of MS components increases, and there is a good correlation between TyG index and TG/HDL-C ratio. This data is consistent with previous evidence that supports TyG index values and TG/HDL-C ratios as IR markers.[6] TyG can help to assess IR as it shows sensitivity (96.5\%) and specificity (85.0\%) when assessed compared to hyperinsulinemic-euglycemic clamp.[11] 
The studies conducted in the non-diabetic population, that the TyG index and TC/HDL-C ratio have a moderate correlation just like the index that uses fasting insulin, assessing glucose absorption by insulin, then this indicates that alternative IR markers based on lipid measurements help detect IR. Due to the similarity of the cut-off index points of TyG to distinguish in men (8.8) and women (8.7) MS in research, sex stratification is considered unnecessary use in daily clinical practice.

However, more studies are needed to validate this index in other populations to generalize the cut-off value. TG/HDL-C ratio value, in the overall MS population, is 2.4, in contrast to TyG index which is different after sex stratification. The cut-off points reported in the study were 2.2 for women and 3.1 for men, similar to the values reported by Salazar et al in Argentina's population (2.5 for women and 3.5 for men).[12] The TG/HDL cholesterol ratio was positively associated with the prevalence of silent brain infarct (SBI) in a neurologically healthy population, [ 13] and an independent predictor of all-cause mortality and cardiovascular events,[14] The TyG index was significantly associated with the risk of incident diabetes and could be a valuable biomarker of developing diabetes,[15] a predictor of incident CKD,[16] and predictor of impaired glucose tolerance in overweight and obese adolescents.[17]

In this study, TyG was significantly correlated with $\mathrm{TC}$, TG, and TG/HDL, leading to cardiovascular risk in dyslipidemia patients.

\section{Conclusions}

There is a significant correlation between tyg reduction with TC, TG and TG/HDL, this leads to cardiovascular risk in dyslipidemia patients.

\section{REFERENCES}

[1] The Miranda PJ, DeFronzo RA, Califf RM, Guyton JR. Metabolic syndrome: definition, pathophysiology, and mechanisms. Am Heart J, vol: 149 Suppl. 1, p:33-45. 2005

[2] Muniyappa R, Lee S, Chen H, Quon MJ. Current approaches for assessing insulin sensitivity and resistance in vivo: advantages, limitations, and appropriate usage. Am J Physiol Endocrinol Metab.vol 294, p:E15-26. 2008

[3] Singh B, Saxena A. Surrogate markers of insulin resistance: a review. World J Diabetes. Vol.1, p:36-47. 2010

[4] Ungera G, Benozzia SF, Perruzzab F, Pennacchiotti GL. Triglycerides and glucose index: A useful indicator of insulin resistance.. Endocrinol Nutr. Vol 61, no. 10, p:533$--540.2014$

[5] Roa Barrios M, Arata-Bellabarba G, Valeri L, Velázquez- Maldonado E. Relación entre el cociente triglicéridos/C-HDL, índices de resistencia a la insulina y factores de riesgo cardiometabólico en mujeres con síndrome del ovario poliquístico. Endocrinol Nutr.vol 56 Suppl. 2,p:59-65.2009 
[6] Guerrero Romero F, Simental Mendia LE, Gonzalez Ortiz M, Martinez Abundis E, Ramos Zavala MG, Hernandez Gonzalez SO, et al. The product of triglycerides and glucose, a simple measure of insulin sensitivity. Comparison with the euglycemic--hyperinsulinemic clamp. J Clin Endocrinol Metab. Vol. 95, p:3347-51. 2010

[7] Wang Y, Koh W, Talaei M, Yuan J, Pan A. Association between the ratio of triglyceride to high- density lipoprotein cholesterol and incident type 2 diabetes in Singapore Chinese men and women. J Diabetes. Vol. 9, no. 7, p:689-698. 2017 doi: 10.1111/1753-0407.12477.

[8] Prianwari C, Lindarto D, Syafril S. Comparison Bay Leaf (Syzygium Polyanthum (Wight) Walp) Ekstrakt With $400 \mathrm{Mg}$ And $600 \mathrm{Mg}$ Dose On Lipoprotein(A) Concentration In Dyslipidemic Patients. International Journal Of Research Science \& Management 6(9): September, 2019

[9] Torre MLDL, Guerrero DB, Cortada JV, González AS, Malpartida KG, HernandezMijares A. Distribución de la circunferencia de la cintura y de la relación circunferencia de la cintura con respecto a la talla según la categoría del índice de masa corporal en los pacientes atendidos en consultas de endocrinología y nutrición. Endocrinol Nutr. Vol. 57 Suppl. 10, p:479---85.2010

[10] Lee EY, Yang HK, Lee J, Kang B, Yang Y, Lee SH, et al. Triglyceride glucose index, a marker of insulin resistance, is associated with coronary artery stenosis in asymptomatic subjects with type 2 diabetes. Lipids Health Dis. Vol. 15, no. 1, p: 155. 2016

[11] Abbasi F, Reaven GM. Comparison of two methods using plasma triglyceride concentration as a surrogate estimate of insulin action in nondiabetic subjects: triglycerides $\AA \sim$ glucose versus triglyceride/high-density lipoprotein cholesterol. Metabolism. Vol. 60,p:1673-6.2011

[12] Salazar MR, Carbajal HA, Espeche WG, Leiva Sisnieguez CE, March CE, Balbín E, et al. Comparison of the abilities of the plasma triglyceride/high-density lipoprotein cholesterol ratio and the metabolic syndrome to identify insulin resistance. Diab Vasc Dis Res. Vol. 10 Suppl. 4,p:346-52. 2013

[13] Nam K, Kwon H, Jeon H, Park J. Kwon H, Jeong S Nam et al. High triglyceride/HDL cholesterol ratio isnassociated with silent brain infarcts in a healthy population. BMC Neurology vol. 19, p:147.1-8. 2019

[14] Bittner V, Delia Johnson B, Zineh E, J. Rogers W, Vido D, Marroquin OC, et al. The TG/HDL Cholesterol Ratio Predicts All Cause Mortality in Women With Suspected Myocardial Ischemia A Report from the Women's Ischemia Syndrome Evaluation (WISE). Am Heart J. vol. 157, no. 3, p: 548-555. 2009

[15] Chamroonkiadtikun P, Ananchaisarp T, Wanichanon W. The triglyceride-glucose index, a predictor of type 2 diabetes development: A retrospective cohort study. Primary Care Diabetes Vol 14, Issue 2, p:161-7. April 2020,

[16] Okamura T, Hashimoto Y, Hamaguchi M, Obora A, Kojima T, Fukui M. Triglycerideglucose index is a predictor of incident chronic kidney disease: a population-based longitudinal study. Clin Exp Nephrol vol. 23, no 7, p:948-55. 2019 doi: 10.1007/s10157-019-01729-2

[17] Phatarakijnirunda V, Kooanantkulb C, Sanora W, Numbenjapona N \& Mungklarata. Triglyceride Glucose Index as a Predictor of Impaired Glucose Tolerance in Overweight and Obese Adolescents P ESPE Abstracts 89 P-P1-069. 2018 